\title{
METHOD OF STRENGTHENING STRUCTURE OF BUILDING
}

\author{
Nusa Setiani Triastuti ${ }^{1}$ \\ ${ }^{1}$ Lecturer of Civil Engineering Department, Faculty of Engineering, Universitas Krisnadwipayana, 13077 \\ e-mail: nusasetiani@unkris.ac.id ${ }^{1}$
}

\begin{abstract}
The owner asks the author to see the condition of the commercial building. The author recognizes that Commercial Buildings do not meet the requirements of the structure of strength, stability, and stiffness. Of the substructure and upper structure of commercial buildings in the business center in Riau Province. Even though they have been built, they do not meet the structural requirements. A thorough analysis is needed from the bottom structure to the top structure. This research aim is strengthening under and upper structure, nothing moving the user and operational — survey methodology with collecting primary and secondary data. Substructure and upper structure data are analyzed for the cause of the damage. The solution is the design and construction stages - design of substructure and upper structure strengthening. The right construction stage applies for an essential role in the success of the construction because the condition of the existing structure from the bottom up is weak. The structural improvement achieved successful results
\end{abstract}

Keywords : Strengthening Structure; Sub Structure; Upper Structure

\section{INTRODUCTION}

Finished Building, Two Year Operational Later, Under Structure until to Roof Closing Have Crack, Deformation This Has Experienced Failure Of Building. Building or infrastructure building failure does not meet the engineering structure requirements. It is namely strength, stability, and stiffness, so the building should not be demolished because the impact will disrupt the concentration of the surrounding buildings. The disruption is dust, noise, vibration, and movements that affect the structure of other buildings, besides the occupants experiencing discomfort.

Cracks, skew/deformation usually precede building structures which reach collapse, then collapse (Crumpton, 2018). These signs are from cracks in the basement, breaks, and slants in the upper structure. When researchers saw the building was anxious and at the same time, scared. With the determination to save the occupants of the building, the writer investigates and provides solutions based on Indonesia Government Regulation number 29 the year 2000, section 31. Construction failure is the condition of the results of construction work that is not following the specifications of the work. It is as agreed in the construction work contract either partially or wholly as a result of the fault of the service user or service provider. Building failure is a condition of a building that does not work in whole or in part in terms of technical aspects, benefits, occupational safety, and health and or public safety. It is as a result of the fault of the Service Provider and Service User after the final construction work (article 34). Construction failure following the Building Law is categorized as building collapse. This because the overall structure down to the upper structure is deformed and cracked.

For the failure rate of buildings, damage identification by collecting primary data. 
It is namely observing visually, including photo documentation, core drill samples, soil investigations) collecting secondary data (drawing documents, shop drawings). Completeness of data and photos of the damage to each structural element is in the attachment.

Although many countries have laws that require the strengthening of earthquakeprone buildings, there are significant obstacles to strengthening these buildings, so they are more resilient. This study examines actions relating to earthquake-prone commercial and public buildings in Wellington and examines private homes after the 2010/2011 Canterbury earthquake and the 2013 Seddon / Cook Strait earthquake. These contradictory findings for EQPBs and Quakechecks suggest the value of the law for encouraging mitigation measures for all buildings (Rae, et al., 2017).

\section{METHODS}

Survey methodology of interviews with building executors and supervisors to determine the implementation of the lower structure and upper structure based on existing building photo. A two-step approach used and discussed below:

First, the supervisor does to the implementation process documents. Lack of documents so focuses on how chronologically the design and implementation is like existing. Second, Executors Executing concrete structures below and above, the process and checking. Secondary data is very minimal, but at least provides input design that is less by structural requirements namely strength, stiffness and stability.

The steps for problem-solving to explain with a flowchart below.

\section{Step Research and Problem-Solving Method of Trengthenig Structure of Building}

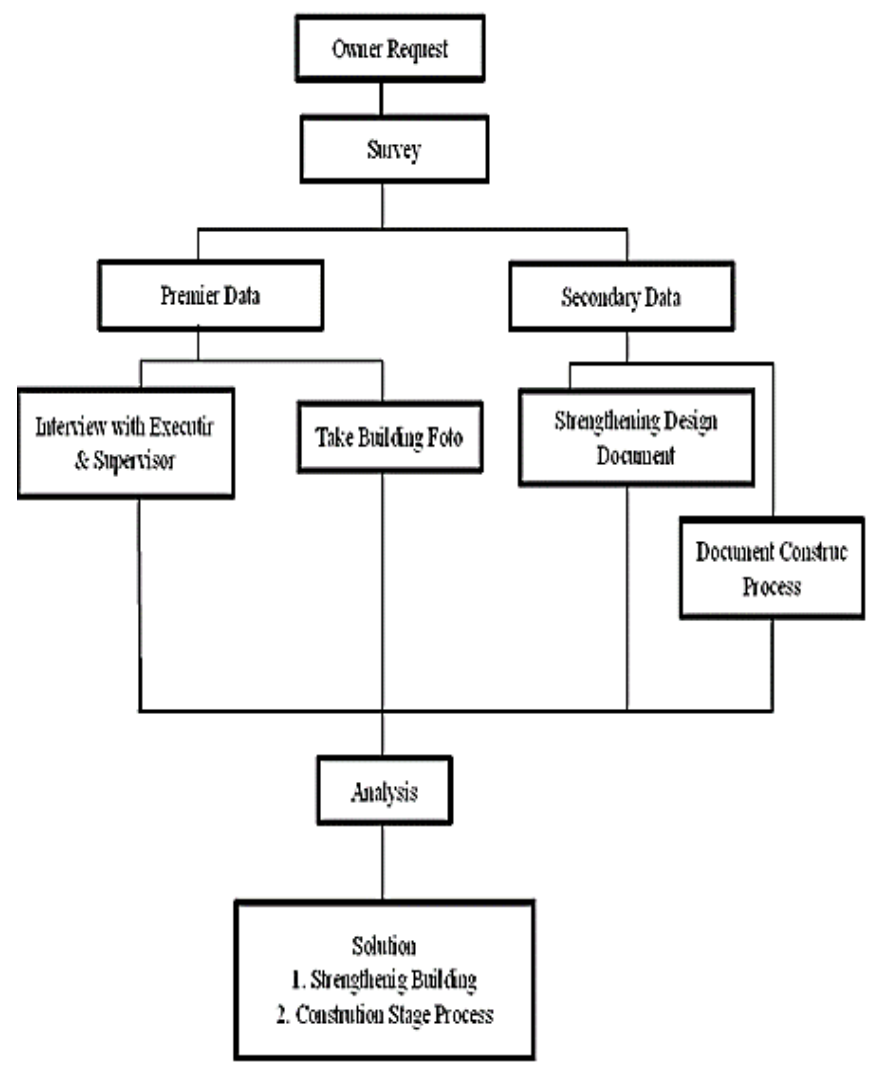




\section{RESULTS AND DISCUSSION}

\section{Substructure}

Plate Structure: broken and deflated $7 \mathrm{~cm}$. The reason is that the foundation is fragile, and the results of soil tests show that the carrying capacity is weak. So it is necessary to add a foundation because the building is ready so that the space for movement is limited, especially the area above. It is a $30 \mathrm{~cm}$ diameter bore pile with a modified tool made loose, so the device enters the building, and installed in the room. The decrease in almost every basement column, even reaching $189 \mathrm{~mm}$ (based on surveyor measurements). Because the foundation of differential settlement occurs, making the column tilted, (Triastuti, 2017) this adds a secondary moment,

$\mathrm{M}=6 \mathrm{EI} \Delta / \mathrm{L} 2$

$\mathrm{E}=$ modulus of elasticity

$\mathrm{I}=$ Inertia moment

$\Delta=$ deflection

$\mathrm{L}=$ length of span

The occurrence of cracks in the span of the walls of shophouses (mostly due to tie beam structure). A foundation settlement causes the Crack. Schmertmann's Method (Hassan, 2017) differential settlement is

\section{$2 \mathrm{~B}$}

$\mathrm{S}=\mathrm{C} 1 \mathrm{C} 2 \mathrm{qn} \sum \mathrm{Iz} / \mathrm{Es} \Delta \mathrm{z}$ for square footing $\omega$

$\mathrm{S}=$ Total Settlement

$\mathrm{qn}=$ net foundation

$\mathrm{q}=$ total foundation pressure $\mathrm{q}=\mathrm{P} / \mathrm{A}+\gamma \mathrm{c}$

Df-U q'o $=\gamma$ soilDf

q'o=effective overburden pressure at

foundation level $\mathrm{q}=\gamma$

$\Delta \mathrm{z}=$ thickness of element layer

$\mathrm{I}=$ vertical strain influence factor

$\mathrm{C} 1=$ depth correction factor

$\mathrm{C} 2=$ creep factor
The floor has decreased (new cracks have returned to old cracks). The crack is caused by the difference in foundation settlement.

\section{Upper Structure Discuss}

The beam is tilted and bent due to casting and settlement differences occur. The steel portal beams are bent and dented. Due to the lack of precision construction. The baseplate has no stiffener. Angkor is only at the front. The pedestal is not with stiffener. Dome always tends to expand and slide. Due to the centrifugal force of the dome with a diameter of $50 \mathrm{~m}$, there is no stiffener base plate. It is not meeting the structural requirements. It can result in long-term fatigue.

Dome with diameter $50 \mathrm{~m}$ is no tensile cable will result in a shift. Especially when working horizontal force, longterm collapse can occur, so it needs given a pull rod.

The broken of beams support the roof column. The principal bearer structure of the roof load and horizontal force must meet the requirements of strong, stable, rigid structures. If not fatal, it will take a victim.

This Floor and corridors are cracked so the upper floor corridor. The structural movements were needed to be strengthened basement roofs with steel profile beams. Unto the steel profile column rests on the pile cape with the added bore pile.

All of the damage in the upper structure, the cause is a fragile foundation with little bearing capacity due to the shallow foundation of the concrete block. So it is necessary to add a $25 \mathrm{~cm}$ mini bore pile foundation with depth is $13 \mathrm{~m}$ (NSPT 32). 
The diameter used is small so that the tool can be modified by making bore piles to end bearings, expected that there will be no differential settlement.

\section{Repairing Upper Structure}

The pedestal column supports the dome diameter of $50 \mathrm{~m}$ replaced by profile steel pedestal. Repairing upper structure addition of:

- Stiffener and $12 \mathrm{~mm}$ round bar bracing and $25 \mathrm{~mm}$ sling on the portal and re-welding on all connections.

- The round bar $16 \mathrm{~mm}$ bracing on the weakest span of the dome structure.

- Steel WF 250,250.11.13.66.5 kg/m.

- Upper structure is as a pedestal dome structure.

- INP steel 400.200.9.11.56.1 kg / m, WF 100,100.9.11.17.2 kg/ m, and plate $4^{\prime} .8^{\prime} .12 \mathrm{~mm} .280 \mathrm{~kg} / \mathrm{sheet}$.

\section{CONCLUSION}

Structural strengthening meets the requirements of strength, stability, and stiffness. This is due to being analyzed thoroughly from the bottom structure to the top structure. Under the structure by the repetition of soil tests, by meeting the requirements Improvement of structure achieved encouraging or successful results. This is due to being analyzed thoroughly from the bottom structure to the top structure. The bottom structure is done by repeating the soil test, by fulfilling the requirements.

\section{ACKNOWLEDGEMENT}

The authors thank the project owner team who helped bring the implementers, supervisors and collect design and implementation documents. The author is asked by the project owner to audit the structure of commercial buildings that operate 1 year but have cracked. Structure design documents, implementation, as-built drawings are very minimal, so it needs to be done again, soil excavation near the foundation, interviews with executors and supervisors to ensure the condition of the structure installed.

\section{REFERENCES}

Crumpton H.(2018) Well Construction and Completion Design, Chapter 2. Well Control for Completions and Interventions Pages 65-85 https://doi.org/10.1016/B978-0-08100196-7.00002-6 Get rights and content

Geldman, L.F.D (2017) The effects of consumer participation in product construction and design on willingness to pay: The case of software. Computers in Human Behavior Vol 75 October 2017, pp 903-911.

Hassan M.A (2017) Modified Schmertmann's Method (1978)for Calculating Settlement In Sand Soils By Using Integration. International Journal of Engineering and Technical Research (IJETR) ISSN: 2321-0869 (O) 2454-4698 (P), Volume-7, Issue-8, August 2017

Indonesia Government regulation Peraturan Pemerintah NO $29 \mathrm{TH}$ 2000

Rae C. $\mathrm{M}_{\mathrm{c}}$,Caspian L.H., Charleson L.A (2017) Reactions to earthquake hazard: Strengthening commercial buildings and voluntary earthquake safety checks on houses in Wellington, New Zealand https://doi.org/10.1016/j.ijdrr.2017.1 $\underline{2.007}$

Triastuti.N.S (2017) Ekspansif Soil Solution in the Villages at Trenggalek. Icon Biuld Proceeding 2017 


\section{Appendix}

When the survey conducted, the substructure was an anomaly.

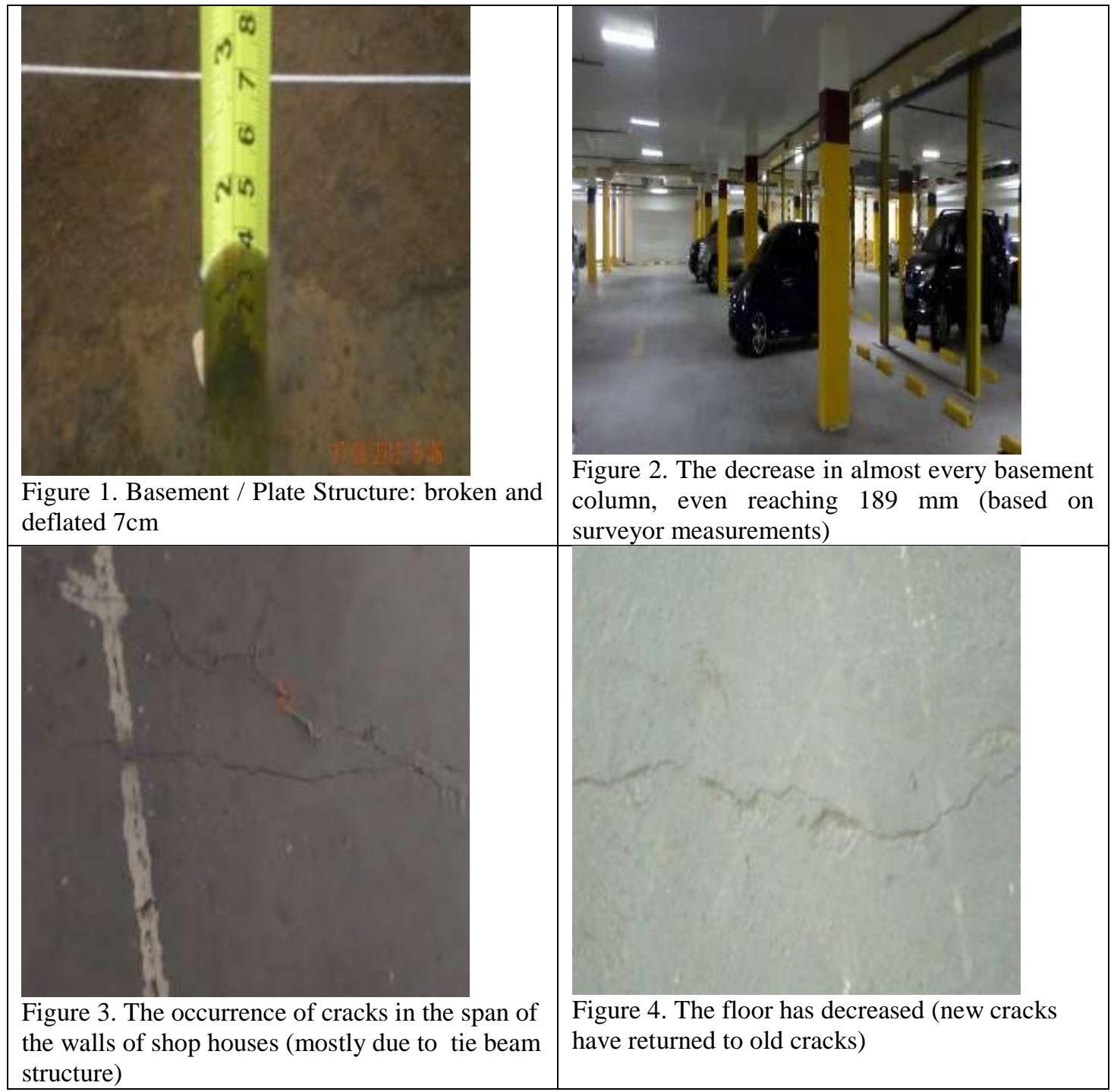

When the survey conducted, the upper structure was anomaly.

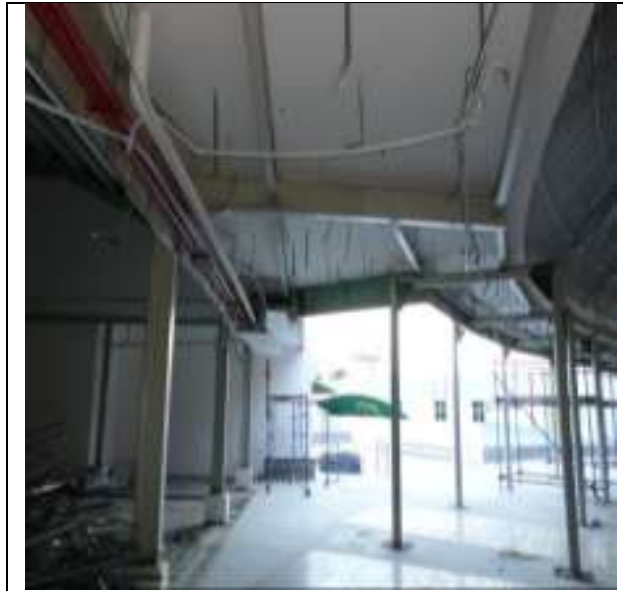

Figure 5. The beam is tilted and bent

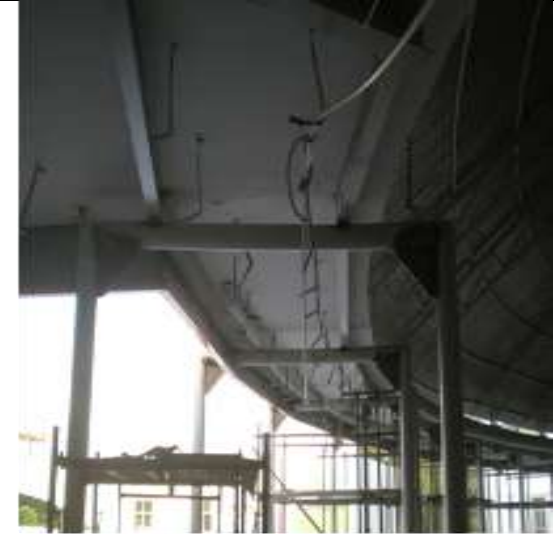

Figure 6 . The steel portal beams are bent and dented 


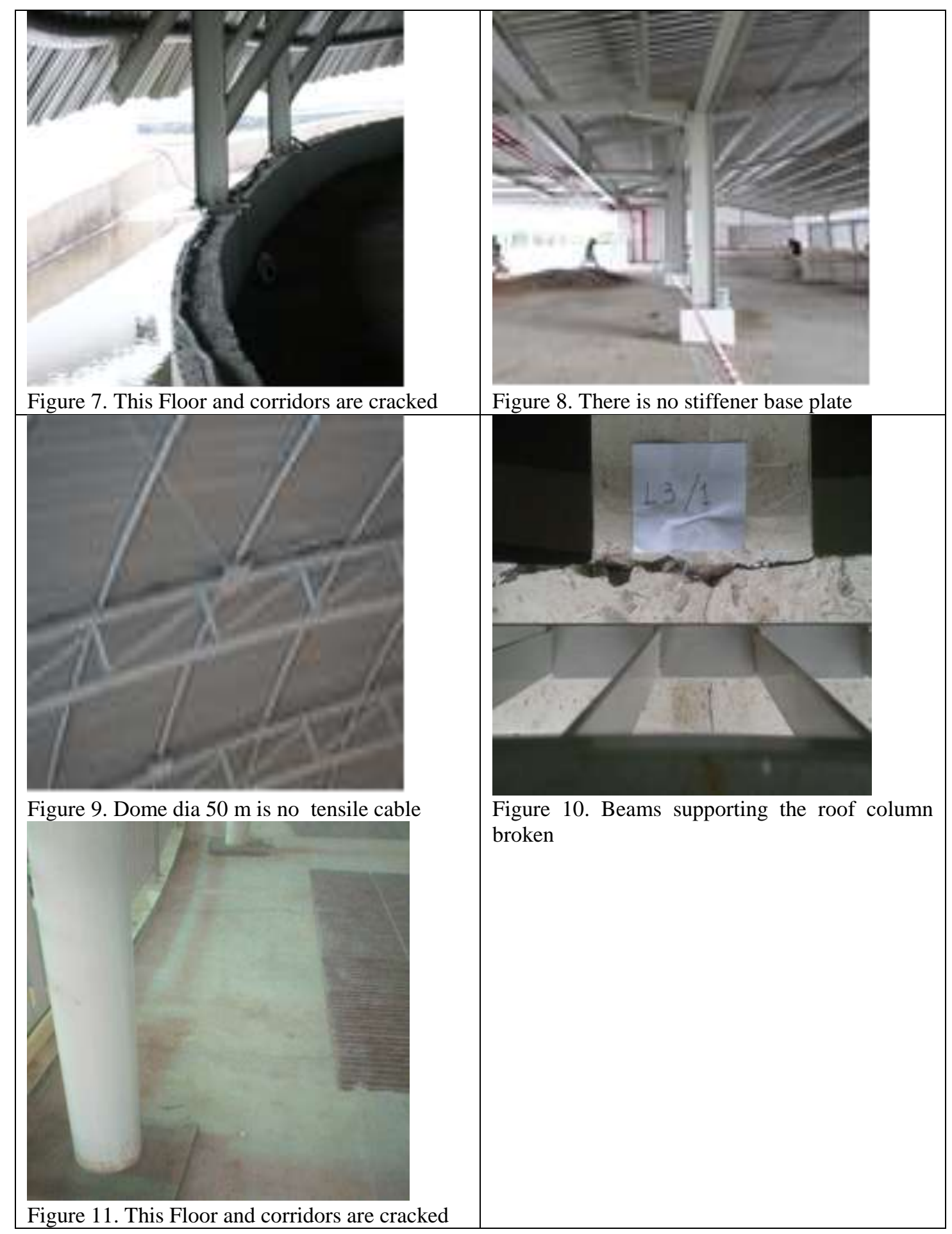

